\title{
浅谈建筑工程造价的合理有效控制与探索
}

\author{
李清霞
}

内丘县住房和城乡建设局

DOI:10.18686/bd.v2i6.1440

[摘 要] 随着社会变化发展以及城市化建设的不断推进, 使得建筑工程项目不断增多, 对建筑工程造价要求也日益严格, 并 且影响建筑工程造价控制因素比较多, 基于此, 本文阐述了建筑工程造价控制的主要作用以及影响建筑工程造价控制的主 要因素,对建筑工程造价控制进行了探讨分析,旨在提高建筑工程的经济效益。

[关键词] 建筑工程; 造价控制; 作用; 重要性; 影响因素; 有效

工程造价对于建筑工程成本控制具有重要作用，其是 建筑工程项目经济效益体现的关键, 因此为了充分发挥工 程造价的作用,必须应用科学、全面、具体以及灵活等手段 进行工程造价,并进行工程造价的全过程控制。

\section{1 建筑工程造价控制的主要作用}

建筑工程造价控制的作用主要体现在：一是用于投资 决策; 二是用于工程招投标; 三是用于筹集资金; 四是用于 工程投资控制; 五是用于工程竣工决算。此外建筑工程造价 还具有以下作用:第一、控制基建工程建设总规模,调节投 资结构,防止盲目建没,重复建设。第二、合理使用人力、物 力、财力和自然资源, 缓解建筑工程投资供需矛盾。第三、加 快工程建设速度,提高投资的经济效益和社会效益,加速基 建工程建设投人产出的良性循环。第四、延长固定资产维修 周期,减少维修开支,降低建筑工程建设全寿命费用。

\section{2 建筑工程造价控制的重要性及其影响因素分析}

2.1 建筑工程造价控制的重要性分析。建筑工程造价作 为一项政策性、专业性和技术性都很强的工作, 是决定工程 建设项目投资效果的重要因素。首先加强对建筑工程造价 控制可以及时纠正建筑施工中所暴露出来的各种问题。在 建筑施工过程中由于施工周期比较长, 经常会因为内外因 素的变化而导致一些问题的出现, 比如因为设计阶段的考 虑不周全而造成工程项目造价上涨, 对此需要及时通过造 价控制采取有效的措施给予解决; 其次工程造价控制可以 有效提高建筑工程的质量与安全。建筑工程造价控制就是 利用经济等手段解决建筑中所存在的问题, 使得建筑质量 更加得到有效的保证。并且做好建筑工程造价控制工作, 不 仅可以节省投资,还可以规范建筑市场的竞争秩序,使建筑 市场健康有序地发展。建筑工程造价贯穿于工程的各个阶 段,要受到多方面的影响,所以工程造价在建筑工程建设阶 段随时可能发生变化, 为了避免因发生大幅度变动的工程 造价对建筑工程影响, 可以通过强化其控制来实现。因此在 建筑工程造价管理过程中, 在有效控制工程造价的同时,提 高造价管理工作效率,使建筑工程造价、进度、质量间的关 系更为协调。

2.2 影响建筑工程造价控制的因素。主要有:(1)概预算
编制因素。建筑工程概预算编制过程中,造价预算编制人员 没有对工程的实际情况进行深人的调查以及研究, 致使编 制出来的建筑工程造价存在着漏项以及缺项等差错, 进而 不能全面细致地反映与正确预测出建筑工程实际施工过程 中需要的费用支出状况。因此缺乏合理性以及科学性的工 程造价不能在实际建筑施工过程中发挥其指导意义。(2)项 目设计因素。第一、由于设计单位没有对项目进行全面的了 解, 只是按照建设单位的主观意愿来理论化设计, 因此, 设计 图和客观条件存在着较大的出人, 对于这种现象通常是边 施工边修改;第二、建设单位和设计单位的沟通不足,致使 设计意图不明确, 在施工的过程中图纸的变更比较大; 第 三、个别建设单位为了使所争取的建设项目能够得到批准, 在报批的过程中故意把投资额改小;第四、部分建设单位在 招标时为了压低其造价，通常会搞一些不切合实际的标准 比较低的设计, 在施工的过程中设计的变更比较大; (3)施工 管理因素。随着建筑规模日趋增大并且变得日益复杂,使得 建筑工程项目的工序比较多、施工时间比较长、场面比较 大,在施工的过程中如果管理不善,那么实际的施工情况就 不能够得到比较及时与准确的反馈, 管理人员就很难对施 工过程中的造价进行有效的监控和调整。在这种情况之下, 很容易出现资金浪费现象,这样也会影响工程造价。

\section{3 建筑工程造价的合理有效控制分析}

3.1 建筑工程项目决策阶段造价控制的分析。项目决策 是从不同角度论证项目的可实施性和必要性以及相关技术 是否支持的过程，项目决策的过程对以后的工程造价和以 后能否盈利有着决定性的作用, 首先在决策中项目的投资 预算是一个重要的环节, 在项目可实行性得到验证后, 就会 开展对项目的投资预算,开始进行资金的注人,所以我们要 求这份投资的预算必须准确,信息是真实的反应,对多个方 案进行分析,选择最优的方案,来使工程更顺利的展开。要做 好项目的投资需要做好事先的准备, 造价工程师要对工程 进行严格的审核, 对所收集的材料要考察其准确性和真实 性, 对建筑所需的材料进行比较, 选择适合工程标准的材料, 在掌握国家和地区政策的时候再决定决策的方向。投资概 算的实施不仅要建立在技术支持的基础上, 还要在经济上 
可行,做到技术和经济的结合。

3.2 建筑工程设计阶段造价控制的分析。主要表现为: (1)科学编制和分解设计概算, 编制精确的施工图预算。在设 计阶段应要求设计单位努力将概算控制在拟定的投资估算 内。在编制过程中将设计概算的投资额和工程量进行分解, 先分解到各个专业, 然后再分解到各单位工程和各分部工 程, 通过层层分解, 实现对设计标准、工程数量、概算指标等 各方面的控制。在工程招投标前应根据施工图编制精确的 施工图预算。(2)合理推行设计招标和设计方案竞选方式选 择设计单位。积极推行建筑方案与经济方案相结合的设计 招标方法,进行多家竞投、由专家组评定,遵循科学方法, 按 照适用、经济、美观的原则以及技术先进、结构合理、满足建 筑节能和环境等要求,综合评定设计方案的优劣。同时中选 方案的投资估算在建设项目的投资范围内。这种方法既有 利于设计方案的选择和竞争, 保证选用的设计方案技术先 进、新颖独特、适应性强, 又能控制工程造价。(3)加强对设计 阶段的全过程跟踪与优化。业主在审查设计单位的设计时, 要重视设计方案的优化, 利用各种指标对总平面图设计、空 间平面设计进行分析比较。运用价值工程原理等优化设计 方案, 提高设计质量, 做到技术与经济的统一。造价人员须及 时对项目投资进行分析对比,反馈造价信息。能动地影响设 计, 优化设计, 以保证有效地控制投资。对内外装饰有特别要 求的建筑项目, 在做建筑设计时就要着手二次装饰的设计, 这将有利于建筑设计与二次装饰有机的结合起来, 同时也 有利于项目的水、电、暖通、电讯、建筑智能化等设计, 有利 于控制工程变更。如:精装小户型工程、酒店工程等。施工图 在招投标前,必须组织设计单位、监理单位及业主的各专业 技术人员进行图纸会审, 发现问题及时修改, 尽量在施工中 不变更。

3.3 建筑工程招投标阶段造价控制的分析。项目工程推 行招投标是为了引进竞争机制对承包单位进行择优选择, 从而达到全面降低工程造价的目的。由于招投标具有极强
的专业性, 主要应从工程量清单的编制人手, 根据编制的标 底来选择最佳的承包单位。对标底进行动态跟踪和控制, 根 据各投标单位的投标报价，对比标底，实时采取控制措施，如 有必要(即原编制的标底不合理或无法实现)还可调整标底。

3.4 建筑工程施工阶段造价控制的分析。建筑工程施工 阶段是把设计变成具有使用价值的实体的过程, 也是建筑 工程造价控制的重要阶段,加强该阶段的造价控制,对有效 抓好资金,提高投资效益有其重大意义。首先应加强施工合 同的管理,对施工单位的施工组织设计进行审核,选择技术 可行性和经济合理性的方案进行施工; 其次, 在施工过程中 加强现场设计代表和现场施工技术人员的经济观念, 积极 配合监理工程师的工作, 加强设计图纸的会审, 及时发现并 解决问题,特别是工程变更的签证必须客观、准确、及时。

3.5 建筑工程竣工结算阶段造价控制的分析。工程建设 完工后并不代表工程造价控制的结束, 一定要做好工程结 算工作,对工程设计和施工中的资料进行整理和分析, 认真 审核数据, 对工程的总费用和其他具体项目的费用做到有 据可循,把用的每一笔资金落到实处, 认真落实好工程的设 计费用和工程的材料费用, 做好材料的价差, 对以后建筑工 程建设会起到一个很好的引导的作用。

\section{4 结束语}

综上所述, 建筑工程造价控制对建设工程各方都具有 重要意义,其可以有效保证工程造价的科学性、准确性、合 理性, 可以加强建筑工程成本控制, 为施工单位服务, 并且可 以提高企业利益, 从而促进建筑行业的健康发展。

\section{参考文献:}

[1]李慧.建筑工程管理中的全过程造价控制分析 [J]. 工程技术研究,2018(03):193-194.

[2]徐静.浅议如何做好建筑工程造价与成本控制[J]. 建筑与预算,2018(05):30-34.

[3]张凯敏.建筑工程造价控制现状及问题研究 [J].建 材与装饰,2018(07):165. 